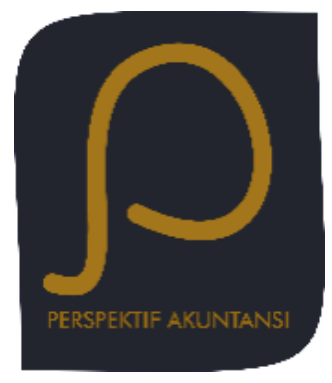

Perspektif Akuntansi

Volume 2 Nomor 3 (Oktober 2019), hal. 249-267

ISSN: 2623-0194 (Print), 2623-0186 (Online)

Copyright@ The Authors(s). All Rights Reserved

Fakultas Ekonomika dan Bisnis,

Universitas Kristen Satya Wacana

DOI: https://doi.org/10.24246/persi.vXiX.p249-267

http://ejournal.uksw.edu/persi

\title{
Tata Kelola Perusahaan dan Penghindaran Pajak
}

Meyjerd Rombebunga ${ }^{1}$

Fakultas Ekonomika dan Bisnis

Universitas Kristen Satya Wacana

David Adechandra Ashedica Pesudo

Departemen Akuntansi

Fakultas Ekonomika dan Bisnis

Universitas Kristen Satya Wacana

Received

15 Mei 2019

Accepted

12 Agustus 2019

\begin{abstract}
This research aims to test the effect of corporate governance characteristic, such as: independent commisaris proportion, audit quality, institusional ownership, and audit commite on tax avoidance. The data used in this study is panel data of 2012-2016 from Mining Corporations listed in Indonesia Stock Exchange. Using quantitative method such as stationary test and panel data regression with Generalized Least Square (GLS) model, this study found that independent commisaris proportion and audit quality have positive and significant effect toward tax avoidance. But, audit commite and institutional ownership have no effect to tax avoidance.
\end{abstract}

Keywords: independent commisaris proportion, audit quality, audit commite, institutional ownership, tax avoidance

Abstrak. Penelitian ini bertujuan untuk menguji pengaruh tata kelola perusahaan, antara lain; proporsi komisaris independen, kualitas audit, kepemilikan institusional, dan komite audit terhadap penghindaran pajak perusahaan. Jenis data yang digunakan dalam penelitian ini adalah data panel dari tahun 2012-2016 pada perusahaan tambang mineral dan batubara yang diperoleh dari Bursa Efek

1232015250@student.uksw.edu 
Indonesia (BEI). Dengan menggunakan metode kuantitatif berupa uji stasioner dan uji regresi data panel dengan model Generalized Least Square (GLS), penelitian ini menunjukkan bahwa proporsi komisaris independen dan kualitas audit berpengaruh positif dan signifikan terhadap penghindaran pajak. Sedangkan, kualitas audit dan kepemilikan institusional tidak berpengaruh terhadap penghindaran pajak.

Kata kunci: proporsi komisaris independen, kualitas audit, kepemilikan institusional, komite audit, penghindaran pajak

\section{Pendahuluan}

Pada tahun 2013 Direktorat Jenderal Pajak (DJP) Kementerian Keuangan Indonesia menyatakan bahwa pajak menyumbang sebesar 70 persen dalam pendapatan negara. Hal ini menunjukkan bahwa pajak mempunyai peran yang vital untuk membiayai berbagai kegiatan operasional pemerintahan. Berdasarkan Undang-Undang Nomor 16 Tahun 2009 Pasal 1 tentang Ketentuan Umum dan Tata Cara Perpajakan, pajak adalah pungutan wajib dan memaksa yang dibebankan kepada orang pribadi atau badan tanpa mendapatkan kontraprestasi secara langsung yang dipakai guna meningkatkan kemakmuran rakyat yang sebesar-besarnya berdasarkan Undang-Undang. Namun, tindakan penghindaran pajak (tax avoidance) masih sering terjadi, termasuk yang dilakukan oleh perusahaan.

Tax avoidance adalah salah satu cara yang ditempuh oleh wajib pajak tanpa melanggar peraturan dalam Undang-Undang perpajakan. Hal ini sejalan dengan Mardiasmo (2013) mengungkapkan bahwa penghindaran pajak adalah usaha untuk mengurangi beban pembayaran pajak yang sesuai dengan ketentuan dalam aturan perpajakan. Artinya, apabila dikaitkan dengan perusahaan, maka manajer perusahaan akan berusaha memaksimalkan penghindaran pajak agar dapat memperbesar laba yang diharapkan oleh berbagai pihak yang berkepentingan dalam perusahaan.

International Monetary Fund (IMF) menginformasikan bahwa pada tahun 2016 penghindaran pajak Indonesia mencapai 6,48 milliar dolar Amerika Serikat dan masuk sebagai peringkat 11 terbesar di dunia, berdasarkan informasi dari tribunnews.com (2017). Secara khusus pada tahun 2015, Publish What You Pay Indonesia melalui kompas.com (2016) menginformasikan bahwa pada tahun 2003-2014 nilai penghindaran pajak perusahaan tambang mineral dan batubara mencapai Rp 235,76 triliun. Pada tahun 2015, Menteri Keuangan Republik Indonesia, Sri Mulyani menyatakan bahwa sekitar 3.600 Surat Pemberitahuan Tahunan pajak penghasilan tidak dilaporkan oleh perusahaan 
tambang mineral dan batubara. Hal ini membuktikan negara mengalami kerugian besar akibat tindakan penghindaran pajak oleh perusahaan tambang mineral dan batubara yang diduga karena adanya peran dalam tata kelola perusahaan.

Penghindaran pajak yang dilakukan oleh berbagai perusahaan dapat mempengaruhi manajer untuk bertindak dengan cara opurtunis dalam rangka mencapai keuntungan (Minnick \& Noga, 2010). Terkait peningkatan laba perusahaan, seperangkat tata kelola perusahaan akan mengendalikan agency problem terkait perilaku tax avoidance demi memperoleh laba yang tinggi dalam periode tertentu (Desai \& Dharmapala, 2006). Hal tersebut berarti principal memberikan tugas tertentu kepada agen, kemudian agen menyetujui untuk melalukan tugas tersebut dengan memberikan beberapa pertimbangan kepada principal. Oleh karena itu, komisaris independen, komite audit, serta kepemilikan institusional diduga berperan dalam melakukan tax avoidance.

Di Indonesia, Eksandy (2017) menemukan komisaris independen berpengaruh positif dan signifikan terhadap penghindaran pajak pada perusahaan yang bergerak di sektor industri barang konsumsi. Demikian pula, kualitas audit ditemukan berpengaruh positif dan signifikan terhadap penghindaran pajak (Annisa \& Kurniasih, 2012). Selanjutnya, kepemilikan institusional terhadap tax avoidance dinyatakan berpengaruh positif (Ngadiman \& Puspitasari, 2014). Kemudian pada perusahaan manufaktur, komite audit dinyatakan berpengaruh positif terhadap aktivitas tax avoidance (Fadhilah, 2014).

Penelitian ini menggunakan perusahaan tambang mineral dan batubara sebagai objek penelitian, khususnya yang terdaftar di Bursa Efek Indonesia (BEI) periode 2012-2016. Objek tersebut dipilih karena perusahaan yang bergerak di sektor tambang mineral dan batubara paling rentan dengan tindakan tax avoidance hingga menyebabkan negara mengalami kerugian yang besar dari sisi penerimaan yang bersumber dari pajak (Patra, 2016). Selain itu, perusahaan tambang memiliki struktur pencatatan akuntansi yang lebih kompleks dan berbeda dari jenis perusahaan lainnya sehingga pihak-pihak dalam tata kelola perusahaan dapat memanfaatkan celah tersebut.

Berdasarkan fakta dan penerapan literatur, maka permasalahan penelitian ini dituangkan dalam bentuk pertanyaan yaitu: 1) apakah proporsi komisaris independen berpengaruh terhadap penghindaran pajak? 2) apakah kualitas audit berpengaruh terhadap penghindaran pajak? dan 3) apakah kepemilikan institusional berpengaruh terhadap penghindaran pajak? serta 4) apakah komite audit berpengaruh terhadap penghindaran pajak?. Penelitian ini diharapkan dapat memberikan kontribusi bagi DJP (Direktorat Jenderal Pajak) terkait faktor-faktor apa saja yang harus diperhatikan mengenai pengaruh tata 
kelola dalam melakukan penghindaran pajak, khususnya di perusahaan tambang mineral dan batubara maupun perusahaan lainnya seperti perusahaan perkebunan, maupun manufaktur.

\section{Telaah Pustaka}

\section{Teori Agensi}

Jensen dan Meckling (1976) menyatakan bahwa agency theory adalah hubungan antara pihak principal dan pihak agency. Apabila mengaitkan teori agensi dengan tax avoidance, Siregar dan Widyawati (2016) mengatakan bahwa adanya kepentingan yang berbeda antara pihak principal dan agency dapat menciptakan tax avoidance. Pihak manajemen selaku agen akan melakukan pekerjaan sesuai keinginan principal selaku pemegang saham. Salah satunya, principal meminta agen untuk melakukan tax avoidance dalam rangka meningkatkan keuntungan perusahaan. Artinya, principal menginginkan tingkat pengembalian yang tinggi dari sumber daya yang telah diinvestasikan, tetapi disisi lain agen akan mementingkan kepentingan pribadinya melalui reward yang akan diperoleh apabila mampu melakukan tax avoidance sesuai keinginan principal.

\section{Penghindaran Pajak}

Penghindaran pajak merupakan pemanfaatan pengecualian dan pemotongan, serta kelemahan dalam peraturan perpajakan untuk menekan biaya pajak (Suandy, 2011). Selanjutnya, , Brian dan Martani (2014) mengatakan sistem pemungutan pajak yang ada di Indonesia menganut sistem self assessment, yaitu kebebasan untuk menghitung, meyetorkan, dan melaporkan kewajiban pajaknya. Artinya, wajib pajak dapat memanfaatkan celah dalam peraturan perpajakan untuk meminimalkan jumlah pembayaran pajaknya. Dalam penelitian ini, tax avoidance diukur menggunakan Book Tax Differences (BTD) yang mengacu pada Tang dan Firth (2012).

BTD dapat menjelaskan hubungan peraturan akuntansi dengan peraturan perpajakan yang membuat perbedaan antara laba fiskal dan laba akuntansi. Artinya, BTD dapat memberikan informasi tentang management discretion dalam proses akrual terkait dengan jumlah perbedaan permanen dan temporer (Tang \& Firth, 2012). Kemudian terkait dengan manipulasi laba, Hanlon dan Shane (2010) mengatakan bahwa BTD dapat dijadikan sebagai acuan dalam menilai agresivitas pelaporan keuangan perusahaan untuk tujuan tax avoidance. Artinya, manajer diberi dua pilihan yaitu; (1) melaporkan laba yang tinggi sehingga beban pajak yang harus dibayarkan ikut meningkat; atau (2) melakukan pelaporan laba yang rendah melalui penghindaran pajak. 


\section{Corporate Governance}

Organisation for Economic Cooperation and Development (2004) menjelaskan bahwa seperangkat hubungan kerjasama antara berbagai direksi, manajemen, pemegang saham, dan dewan komisaris, serta para pemangku kepentingan disebut sebagai corporate governance. Keputusan-keputusan strategis perusahaan sangat dipengaruhi oleh corporate governance. Salah satunya adalah usaha menghindari beban pajak perusahaan. Keterkaitan corporate governance dengan penghindaran pajak juga dijelaskan oleh Desai dan Dharmapala (2006) bahwa shareholder menginginkan laba yang tinggi. Pemegang saham (principal) menuntut pihak manajer (agency) untuk melakukan tax avoidance. Artinya, ketika para manajer mampu meminimalkan beban pajak yang akan dibayar oleh perusahaan maka semakin besar laba yang akan diperoleh perusahaan, khususnya pemegang saham.

\section{Pengembangan Hipotesis}

\section{Pengaruh Proporsi Komisaris Independen terhadap Penghindaran Pajak}

Berdasarkan Undang-Undang Republik Indonesia Nomor 40 Tahun 2007 tentang Perseroan Terbatas, dewan komisaris adalah anggota perusahaan yang berdasarkan anggaran dasar bertugas melakukan pengawasan umum dan khusus terhadap kebijakan dewan direksi. Dalam rangka melakukan pengawasan secara maksimal, Peraturan Otoritas Jasa Keuangan (POJK) Nomor 33/POJK.04/2014 Pasal 20 Ayat 3 tentang Direksi dan Dewan Komisaris Emiten atau Perusahaan Publik menetapkan bahwa perusahaan wajib memiliki paling kurang 30 persen dewan komisaris independen.

Selanjutnya, Minnick dan Noga (2010) menemukan bahawa semakin besar jumlah ukuran dewan komisaris maka semakin besar pula tindakan penghindaran pajaknya. Hal ini didukung oleh Lanis dan Richardson (2011), Timothy (2010), serta Eksandy (2017) menemukan pengaruh positif dan signifikan antara proporsi komisaris independen terhadap penghindaran pajak. Artinya, semakin banyak dewan komisaris independen akan meningkatkan penghindaran pajak perusahaan. Hal ini dikarenakan komisaris independen akan berusaha untuk memaksimalkan kinerjanya terkait tugasnya untuk melakukan pengawasan terhadap usaha memaksimalkan laba perusahaan melalui penghindaran pajak dengan mengandalkan wawasan dan pengalaman mereka (Minnick \& Noga, 2010). Hal ini sejalan dengan Sabli dan Noor (2012) mengatakan bahwa salah satu cara mendapatkan profitabilitas adalah dengan melakukan penghindaran pajak yang wajib diawasi oleh dewan komisaris independen demi mementingkan kepentingan pemegang saham. Oleh karena itu, rumusan hipotesis sebagai berikut: 
$\mathbf{H}_{1}$ : Proporsi komisaris independen berpengaruh positif terhadap penghindaran pajak

\section{Pengaruh Kualitas Audit terhadap Penghindaran Pajak}

Kualitas audit yaitu laporan yang dihasilkan oleh auditor atas pemeriksaan laporan keuangan mengenai kemungkinan kesalahan atau pelanggaran dalam laporan keuangan perusahaan (Dewi \& Jati, 2014). Kemudian, ukuran sebuah Kantor Akuntan Publik (KAP) dapat mencerminkan kualitas auditnya (DeAngelo, 1981). KAP yang besar (Big Four Accounting Firms) diyakini memiliki kualitas yang lebih baik dibandingkan dengan KAP Non-Big Four Firms dalam melakukan pemeriksaan laporan keuangan. Hal ini dikarenakan KAP Big Four sering melakukan pelatihan dalam skala internasional, sehingga dianggap lebih berkompeten dalam melakukan tugas audit (Nindita \& Siregar, 2012).

Selanjutnya, Annisa dan Kurniasih (2012), serta Eksandy (2017) menyatakan bahwa tax avoidance dipengaruhi secara positif oleh kualitas audit. Kualitas audit yang semakin baik membuat tax avoidance perusahaan semakin tinggi. Hal ini disebabkan oleh adanya hasil audit laporan keuangan perusahaan yang diaudit oleh Big Four Accounting Firms dipercaya memiliki kualitas lebih baik. Dalam rangka melakukan tax avoidance, Cai dan Liu (2009) perusahaan dituntut membuat laporan keuangan yang memiliki kualitas audit baik agar dapat melakukan penghindaran pajak. Oleh karena itu, hipotesis sebagai berikut:

$\mathbf{H}_{2}$ : Kualitas audit berpengaruh positif terhadap penghindaran pajak

\section{Pengaruh Kepemilikan Institusional terhadap Penghindaran Pajak}

Kepemilikan institusional yaitu kepemilikan saham selain kepemilikan individual yang berasal dari luar perusahaan (Dewi \& Jati, 2014). Selanjutnya, Pujiati dan Widanar (2009) mengatakan kepemilikan institusional secara mayoritas dan minoritas masing-masing memiliki proporsi sebesar lima persen dan kurang dari lima persen. Hal ini berarti pemilik saham institusional memiliki otoritas yang kuat untuk mengawasi dan mempengaruhi manajer (Ngadiman \& Puspitasari, 2014).

Selanjutnya, terkait dengan perilaku tax avoidance, Khurana dan Moser (2009) mengungkapkan persentase kepemilikan saham institusional dapat mempengaruhi tindakan manajer. Selanjutnya, Ngadiman dan Puspitasari (2014) menemukan bahwa kepemilikan institusional memiliki pengaruh positif dan signifikan terhadap tax avoidance. Artinya, semakin meningkatnya jumlah kepemilikan saham institusional pada perusahaan akan meningkatkan tindakan penghindaran pajak yang dilakukan dengan meminimalkan beban pajak perusahaan (Idzni \& Purwanto, 2017). Hal ini dikarenakan pemilik saham 
institusional berdasarkan besar dan hak suara yang dimiliki, dapat memaksa manajer untuk berfokus pada kinerja ekonomi agar memperoleh laba yang tinggi dengan cara melakukan penghindaran pajak. Oleh karena itu, hipotesis sebagai berikut:

$\mathbf{H}_{3}$ : Kepemilikan institusional berpengaruh positif terhadap penghindaran pajak

\section{Pengaruh Komite Audit terhadap Penghindaran Pajak}

Komite audit adalah pemeriksa laporan keuangan yang jumlahnya minimal tiga orang dalam sistem tata kelola Indonesia, serta dibentuk, diangkat, dan diberhentikan oleh dewan komisaris (Winata, 2014). Selanjutnya, Sriwedari (2012) menyatakan bahwa keberadaan komite audit bertugas untuk menjaga dan meningkatkan integritas serta kredibilitas laporan keuangan perusahaan.

Annisa dan Kurniasih (2012), serta Fadhilah (2014) menemukan bahwa tax avoidance dipengaruhi positif dan signifikan oleh kualitas audit. Kemudian, Robinson et al. (2012) menyatakan bahwa dalam pajak yang tidak terlalu memiliki risiko tinggi, komite audit bepengaruh positif terhadap tax avoidance perusahaan. Hal ini dapat menjelaskan bahwa kinerja keuangan akan menjadi fokus utama oleh komite audit, khususnya terkait penghematan dana perusahaan dengan cara yang benar. Artinya, komite audit akan melakukan pengawasan secara maksimal untuk menjaga kredibilitas dan integritas laba perusahaan melalui pelaporan keuangan yang dikeluarkan agar tidak menyesatkan dan sesuai standar akuntansi, serta memastikan tidak ada penyimpangan yang material dibidang keuangan sehingga aman untuk melakukan penghindaran pajak. Hal ini sejalan dengan Suryana (2005) menjelaskan bahwa laba yang lebih tinggi akan diperoleh apabila suatu entitas bisnis memiliki komite audit. Oleh karena itu, rumusan hipotesisnya sebagai berikut:

$\mathbf{H}_{4}$ : Komite audit berpengaruh positif terhadap penghindaran pajak

\section{Metoda}

Sebagai penelitian kuantitatif yang menggunakan data sekunder berupa data panel yang terdiri atas data time series dan cross section diperoleh populasi sebesar 41 perusahaan tambang mineral dan batubara yang terdaftar di BEI periode 2012-2016. Selanjutnya, teknik purposive sampling digunakan untuk memperoleh sampel dengan beberapa kriteria yaitu: 1) perusahaan yang listed di BEI antara tahun 2012-2016 yang memiliki laporan keuangan tahunan yang lengkap, khusunya di bidang tambang mineral dan batubara; 2) memiliki laba; dan 3) periode pelaporan keuangan per 31 Desember. Dengan demikian, 
diperoleh sampel akhir sebanyak 65 sampel yang meliputi 13 perusahaan dengan lima periode observasi yaitu tahun 2012-2016.

\section{Definisi dan Pengukuran Variabel}

Variabel dalam penelitian ini yang terdiri atas satu variabel dependen dan lima variabel independen sebagai berikut.

\section{Tabel 1. Pengukuran Variabel Penelitian}

\begin{tabular}{|c|c|c|c|c|c|}
\hline No. & Variabel & Definisi & Indikator & Skala & Rumus \\
\hline 1 & $\begin{array}{c}\text { Penghindaran } \\
\text { Pajak (Y) }\end{array}$ & $\begin{array}{c}\text { Mengurangi } \\
\text { beban pajak } \\
\text { tanpa melanggar } \\
\text { hukum (Suandy, } \\
\text { 2011). }\end{array}$ & $\begin{array}{c}\text { Book Tax } \\
\text { Difference } \\
\text { (BTD). }\end{array}$ & Rasio & $\begin{array}{l}\text { BTD } \\
=\frac{\text { LA - PKP }}{\text { TA }} \\
\text { BTD: Book tax } \\
\text { difference } \\
\text { LA: Laba } \\
\text { akuntansi } \\
\text { PKP: } \\
\text { Penghasilan } \\
\text { kena pajak } \\
\text { TA: Total aset }\end{array}$ \\
\hline 2 & $\begin{array}{c}\text { Proporsi } \\
\text { Komisaris } \\
\text { Independen } \\
\text { (X1) }\end{array}$ & $\begin{array}{c}\text { Organ perseroan } \\
\text { yang melakukan } \\
\text { pengawasan } \\
\text { umum dan } \\
\text { khusus kepada } \\
\text { dewan direksi } \\
\text { (UU RI No. } 40 \\
\text { tentang } \\
\text { Perseroan } \\
\text { Terbatas Tahun } \\
\text { 2007). }\end{array}$ & $\begin{array}{c}\text { Jumlah } \\
\text { anggota } \\
\text { komisaris } \\
\text { independen. }\end{array}$ & Rasio & $\begin{array}{c}\mathrm{PKI}=\frac{\mathrm{JKI}}{\mathrm{JSK}} \\
\text { PKI: Proporsi } \\
\text { komisaris } \\
\text { independen } \\
\text { JKI: Jumlah } \\
\text { komisaris } \\
\text { independen } \\
\text { JSK: Jumlah } \\
\text { seluruh } \\
\text { anggota dewan } \\
\text { komisaris } \\
\text { independen }\end{array}$ \\
\hline 3 & $\begin{array}{c}\text { Kualitas } \\
\text { Audit (X2) }\end{array}$ & $\begin{array}{c}\text { Pemeriksaan } \\
\text { laporan } \\
\text { keuangan oleh } \\
\text { auditor (Dewi \& } \\
\text { Jati, 2014) }\end{array}$ & $\begin{array}{c}\text { Audit Big } \\
\text { Four dan } \\
\text { Non-Big } \\
\text { Four. }\end{array}$ & Nominal & $\begin{array}{c}\text { Dummy: } \\
1=\text { KAP Big } \\
\quad \text { Four } \\
0=\text { KAP non- } \\
\text { Big Four }\end{array}$ \\
\hline 4 & $\begin{array}{l}\text { Kepemilikan } \\
\text { Institusional } \\
\text { (X3) }\end{array}$ & $\begin{array}{c}\text { Kepemilikan } \\
\text { selain individual } \\
\text { yang berasal } \\
\text { dari luar } \\
\text { perusahaan } \\
\text { (Dewi \& Jati, } \\
2014 \text { ). }\end{array}$ & $\begin{array}{c}\text { Jumlah } \\
\text { proporsi } \\
\text { kepemilikan } \\
\text { saham oleh } \\
\text { institusi } \\
\text { lain. }\end{array}$ & Rasio & $\begin{array}{c}\text { KIS }=\frac{J S I}{\text { TMS }} \\
\text { KIS: } \\
\text { Kepemilikan } \\
\text { institusional } \\
\text { JSI: Jumlah } \\
\text { saham yang } \\
\text { dimiliki } \\
\text { investor } \\
\text { institusi }\end{array}$ \\
\hline
\end{tabular}




\begin{tabular}{|c|c|c|c|c|c|}
\hline No. & Variabel & Definisi & Indikator & Skala & Rumus \\
\hline & & & & & $\begin{array}{c}\text { TMS: Total } \\
\text { modal saham } \\
\text { yang beredar }\end{array}$ \\
\hline 6 & $\begin{array}{l}\text { Komite Audit } \\
\text { (X5) }\end{array}$ & $\begin{array}{c}\text { Komite yang } \\
\text { bertugas } \\
\text { memeriksa } \\
\text { laporan } \\
\text { keuangan } \\
\text { (Winata, 2014). }\end{array}$ & $\begin{array}{l}\text { Jumlah } \\
\text { anggota } \\
\text { komite } \\
\text { audit. }\end{array}$ & Rasio & $\begin{array}{c}\text { KOA }=\sum \text { komite } \\
\text { audit }\end{array}$ \\
\hline
\end{tabular}

\section{Uji Stasioneritas Data Panel}

Penelitian ini harus memenuhi asumi stasioneritas terlebih dahulu agar tidak memiliki akar unit atau varians yang terlalu jauh atau mendekati nilai rataratanya.

Dengan hipotesis sebagai berikut:

Ho: terdapat akar unit

Ha: tidak terdapat akar unit,

Kemudian akan diamati menggunakan metode Uji Levin, Lin \& Chu. Setelah itu, jika data tidak stasioner pada order nol [I(0)], maka perlu dilakukan uji stasioneritas data pada order berikutnya yaitu first difference dan second difference. Dengan demikian, model yang digunakan untuk pengujian stasioneritas yaitu (Granger, 1974):

$Y_{i t}=\rho_{i} Y_{i t-1}+X_{i t} \delta_{i}+\epsilon_{i t}$

$Y_{i t}$ mewakili variabel pooled, $X_{i t}$ mewakili variabel eksogen dalam model, termasuk efek tetap atau tren individual, $\rho_{\mathrm{I}}$ adalah koefisien autoregresif, dan errors $_{i t}$ diasumsikan sebagai gangguan idiosyncratic yang saling terpisah.

\section{Uji Regresi Data Panel}

Pada uji regresi data panel perlu dilakukan uji spesifikasi model untuk mengetahui model yang akan digunakan. Menurut Winarno (2015)model regresi data panel yang dapat digunakan yaitu random effect yang ditunjukkan secara berurutan sebagai berikut:

$\mathrm{TA}_{\mathrm{it}}=\beta_{0 \mathrm{i}}+\beta_{1} \mathrm{PKI}_{\mathrm{it}}+\beta_{2} \mathrm{KAU}_{\mathrm{it}}+\beta_{3} \mathrm{KIS}_{\mathrm{it}}+\beta_{4} \mathrm{KOA}_{\mathrm{it}}+\mathrm{e}_{\mathrm{it}}(2)$

Keterangan:

$\mathrm{TA}_{\mathrm{it}} \quad=\quad$ tax avoidance perusahaan $\mathrm{i}$ tahun $\mathrm{t}$

$\mathrm{PKI}_{\mathrm{it}}=$ proporsi komisaris independen perusahaan $\mathrm{i}$ tahun $\mathrm{t}$

$\mathrm{KAU}_{\mathrm{it}} \quad=\quad$ kualitas audit perusahaan $\mathrm{i}$ tahun $\mathrm{t}$

$\mathrm{KIS}_{\mathrm{it}}=$ kepemilikan institusional perusahaan $\mathrm{i}$ tahun $\mathrm{t}$ 


$\begin{array}{lll}\mathrm{KOA}_{\mathrm{it}} & = & \text { komite audit perusahaan i tahun } \mathrm{t} \\ \aleph_{0 \mathrm{i}} & = & \text { unobserved time-invariant individual effect } \\ \aleph_{1}, \aleph_{2}, \bigotimes_{3}, \aleph_{4} & = & \text { koefisien regresi } \\ \text { eit } & = & \text { error term perusahaan } \mathrm{i} \text { tahun } \mathrm{t}\end{array}$

\section{Hasil dan Pembahasan}

\section{Hasil}

Berikut hasil pengujian dan pembahasan dari pengujian stasioner dan uji regresi data panel adalah sebagai berikut:

\section{Statistik Deskriptif}

Analisis statistik deskriptif bertujuan untuk mengetahui nilai mean, maksimum, minimum dan standar deviasi dari variabel-variabel yang digunakan dalam penelitian ini.

\section{Tabel 2. Statistik Deskriptif}

\begin{tabular}{cccccc}
\hline & $\mathrm{N}$ & Minimum & Maximum & Mean & Std. Deviation \\
\hline BTD & 65 & 0.000140 & 1060.080 & 239.0007 & 339.2930 \\
PKI & 65 & 0.111111 & 0.666667 & 0.367729 & 0.121952 \\
KAU & 65 & 0.000000 & 1.000000 & 0.492308 & 0.503831 \\
KIS & 65 & 0.090000 & 52.21000 & 3.037494 & 10.90277 \\
KOA & 65 & 2.000000 & 5.000000 & 3.138462 & 0.609224 \\
\hline
\end{tabular}

Sumber: Data Diolah, (2018)

Berdasarkan Tabel 2, dapat diketahui bahwa jumlah sampel yang di teliti adalah 65 sampel. Sebagai varibel dependen, nilai mean 239.00 dengan nilai terendah 0.00 dan nilai tertinggi sebesar 1060.08 serta standar deviasi sebesar 339.29. Artinya, apabila nilai akrual suatu perusahaan semakin kecil maka tingkat penghindaran pajak tersebut semakin tinggi. Sedangkan, proporsi komisaris independen mempunyai nilai rata-rata sebesar 0.36 dengan nilai minimum dan maksimum masing-masing sebesar 0.11 dan 0.66 dengan standar deviasi sebesar 0.12 . Nilai mean tersebut dapat menunjukkan bahwa semakin banyak jumlah komisaris independen maka semakin tinggi penghindaran pajak perusahaan.

Kemudian, kualitas audit memiliki nilai minimum dan maksimum masingmasing sebesar 0.00 dan 1.00 dengan nilai mean dan standar deviasi secara berurutan sebesar 0.49 dan 0.50 . Nilai rata-rata yang signifikan berarti semakin baik kualitas audit sebuah perusahaan maka penghindaran pajaknya semakin tinggi. 
Selanjutnya, kepemilikan institusional menunjukkan nilai minimum, maksimum, mean dan standar deviasi secara berurutan sebesar 0.09, 52.21, 3.03, dan 10.90. Nilai mean yang signifikan berarti semakin tinggi jumlah kepemilikan institusional maka perilaku penghindaran pajak akan semakin tinggi.

Selain itu, variabel komite audit memiliki nilai minimum, maksimum dan standar deviasi masing-masing sebesar 2.00, 5.00, dan 0.60. Sedangkan nilai rata-rata sebesar 3.13. Nilai mean tersebut menunjukkan bahwa komite audit akan berusaha semaksimal mungkin agar perusahaan memiliki laporan keuangan yang sesuai dengan standar akuntansi sehingga aman untuk melakukan penghindaran pajak.

\section{Uji Stasioneritas Data Panel}

Penelitian ini terlebih dahulu harus memenuhi syarat lolos uji stasioner atau memiliki data yang stasioner. Uji stasioner diamati menggunakan metode Uji Levin, Lin \& Chu. Hasil pengolahan data untuk uji stasioner ini dapat dilihat pada Tabel 3.

\section{Tabel 3. Hasil Uji Stasioneritas Data Panel}

\begin{tabular}{cccc}
\hline \multirow{2}{*}{ Variabel } & Derajat Integrasi & \multirow{2}{*}{ Prob. } \\
\cline { 3 - 3 } & & \multicolumn{2}{c}{ Uji Levin, Lin, \& } \\
Chu & \\
\hline BTD & Level & 0.00 & $\mathrm{I}(0)$ \\
PKI & Level & 0.00 & $\mathrm{I}(0)$ \\
KAU & Level & 0.02 & $\mathrm{I}(0)$ \\
KIS & Level & 0.00 & $\mathrm{I}(0)$ \\
KOA & Level & 0.00 & $\mathrm{I}(0)$ \\
\hline
\end{tabular}

Sumber: Data Diolah, (2018)

Berdasarkan Tabel 3, dapat disimpulkan bahwa variabel penghindaran pajak, proporsi komisaris independen, kualitas audit, kepemilikan institusional, dan komite audit pada derajat level (I(0)) menerima Ho yang ditunjukkan melalui nilai probabilitas pada Uji Levin, Lin \& Chu lebih kecil dari pada taraf nyata $(\alpha=5 \%)$ yaitu masing-masing sebesar $0.00,0.02,0.00,0.00,0.00$ yang berarti terdapat akar unit.

Dengan demikian variabel penghindaran pajak, proporsi komisaris independen, kualitas audit, kepemilikan institusional, serta komite audit telah bersifat stasioner atau data telah memiliki varians yang tidak terlalu besar dan kecenderungan untuk mendekati nilai rata-ratanya sehingga layak dalam pengujian selanjutnya. 


\section{Analisis Data Panel}

Sebelum melakukan uji regresi data panel, maka terlebih dahulu dilakukan pengujian kesesuaian model untuk memperoleh model terbaik. Hal ini dapat ditempuh dengan cara melakukan uji chow dan uji hausman, yang hasilnya dapat dilihat pada Tabel 4 .

\section{Tabel 4. Uji Spesifikasi Model}

\begin{tabular}{ccc}
\hline & Prob. & Model Estimasi Terbaik \\
\hline Uji Chow & 0.00 & Fixed Effect \\
Uji Hausman & 0.18 & Random Effect \\
\hline
\end{tabular}

Sumber: Data Diolah, (2018)

Hasil pengujian di atas menunjukkan bahwa pada uji chow nilai probabilitas yang lebih kecil dari nilai taraf nyata $(\alpha=5 \%)$ yaitu sebesar 0.00 menyatakan Ho ditolak dan menerima Ha yaitu pemilihan model yang paling tepat ialah fixed effect dibandingkan dengan model common/pool effect. Karena model terbaik ialah fixed effect maka perlu dilakukan langkah selanjutnya untuk membandingkan model random effect dan fixed effect, yang disebut juga dengan uji hausman. Pada uji hausman nilai probabilitas lebih besar dari nilai taraf nyata $(\alpha=5 \%)$ yang menunjukkan bahwa Ho diterima dan menolak Ha yaitu model terbaik yang akan digunakan ialah random effect dikarenakan nilai probabilitasnya lebih besar dari $(\alpha=5 \%)$ yaitu sebesar 0.18

Dalam eviews, metode Generalized Least Square (GLS) hanya digunakan pada random effect model, sedangkan fixed effect dan common effect menggunakan Ordinary Least Square (OLS). Berdasarkan hasil pengujian di atas, maka model terbaik adalah random effect. Menurut Gujarati dan Poter (2012), dengan menggunakan metode GLS maka data tersebut memenuhi persamaan asumsi klasik. Oleh karena itu, tidak perlu melakukan uji asumsi klasik. Selanjutnya, melakukan pengujian dengan model random effect maka diperoleh hasil sebagai berikut:

Tabel 5. Hasil Uji Random Effect Model

\begin{tabular}{cccc}
\hline Variabel & Koefisien & t-Statistic & Prob. \\
\hline C & -290.66 & -1.12 & 0.26 \\
PKI & 706.56 & 2.14 & 0.03 \\
KAU & 251.22 & 2.17 & 0.03 \\
KIS & -0.13 & -0.05 & 0.95 \\
KOA & 46.70 & 0.78 & 0.43 \\
R-squared & 0.13 & & \\
Prob (F-statistic) & 0.07 & & \\
\hline
\end{tabular}

Sumber: Data Diolah, (2018) 
Hasil uji random effect model secara umum menunjukkan proporsi komisaris independen dan kualitas audit diterima. Sedangkan kepemilikan institusional dan komite audit ditolak. Hal ini dibuktikan melalui proporsi komisaris independen dan kualitas audit memiliki pengaruh yang positif dan signifikan yang ditunjukan secara berturut-turut melalui nilai koefisien sebesar 706.56 dan 251.22 serta nilai prob lebih kecil dari $(\alpha=5 \%)$ yaitu sebesar 0.03 dan 0.03 . Selanjutnya, kepemilikan institusional dan komite audit tidak memiliki pengaruh yang dapat dilihat melalui nilai probabilitas lebih besar dari $(\alpha=5 \%)$ yaitu masing-masing bernilai sebesar 0.95 dan 0.43. Mengingat data yang digunakan adalah data panel, maka kondisi tiap objek (perusahaan) saling berbeda, sehingga perlu memperhatikan perbedaan konstannya meskipun dengan koefisien regresor yang sama (Winarno, 2015). Hal ini dapat dilihat melalui Tabel 6 berikut ini:

\section{Tabel 6. Pengaruh cross section}

\begin{tabular}{cccc}
\hline Perusahaan & Pengaruh & Perusahaan & Pengaruh \\
\hline ADRO & 269.29 & ITMG & 542.84 \\
ARTI & -150.38 & KKGI & 491.74 \\
CTTH & -77.75 & MYOH & 387.99 \\
ELSA & -423.41 & RUIS & -81.83 \\
ESSA & -267.22 & TINS & -391.70 \\
GEMS & -437.46 & TOBA & 304.34 \\
INCO & -166.42 & & \\
\hline
\end{tabular}

Sumber: Data Diolah, (2018)

Hasil pengujian di Tabel 6 menunjukkan bahwa kurang lebih 61 persen perusahaan dari total 13 perusahan tambang mineral dan batubara memiliki nilai konstan negatif (-) yang berarti disaat proporsi komisaris independen, kualitas audit, kepemilikan institusional, dan komite audit bernilai nol (0) maka tingkat penghindaran pajak akan mengalami penurunan sebesar nilai konstannya. Perusahaan tersebut adalah ARTI, CTTH, ELSA, ESSA, GEMS, INCO, RUIS dan TINS. Sedangkan sisanya yaitu sekitar 39 persen memiliki nilai konstan positif $(+)$ yang berarti dengan tidak adanya proporsi komisaris independen, kualitas audit, kepemilikan institusional, dan komite audit atau bernilai nol (0) maka tingkat penghindaran pajaknya akan meningkat sebesar nilai konstannya.

\section{Pembahasan}

Pengujian regresi data panel yang mencakup 13 perusahaan tambang mineral dan batubara dari tahun 2012-2016 menunjukkan hasil yang berbeda-beda pada setiap variabel. Hasil yang diperoleh menunjukkan bahwa proporsi komisaris independen berpengaruh positif dan signifikan terhadap tax avoidance. Hal ini sejalan dengan Lanis dan Richardson (2011), Timothy 
(2010), serta Eksandy (2017) menyatakan bahwa anggota komisaris independen yang banyak akan memaksimalkan kinerja atau tugasnya dalam melakukan pengawasan terhadap usaha memaksimalkan laba perusahaan dengan cara melakukan penghindaran pajak. Hal ini ditempuh agar perusahaan dapat melakukan penghematan kas sehingga kinerja keuangan perusahaan baik. Artinya, penghindaran pajak akan semakin tinggi apabila komisaris independen mampu memenuhi peran mereka dalam mengawasi dan mengontrol tindakan-tindakan para direktur eksekutif terkait penghematan kas.

Selanjutnya, hasil penelitian kualitas audit memiliki pengaruh signifikan dan positif terhadap penghindaran pajak. Hal ini sejalan dengan Eksandy (2017), Annisa dan Kurniasih (2012) menyatakan bahwa penghindaran pajak dipengaruhi secara positif oleh kualitas audit. Artinya, audit laporan keuangan tersebut bertujuan untuk menentukan apakah laporan keuangan yang diterbitkan atau disajikan oleh perusahaan sudah sesuai dengan Standar Akuntansi Keuangan (SAK) atau prinsip akuntansi yang berterima umum, sehingga tidak sampai mengukur ada tidaknya tindakan tax avoidance perusahaan. Hal ini dikarenakan KAP lebih tertuju pada audit laporan keuangan (Dewi \& Sari, 2015). Sedangkan yang lebih berwenang untuk mengukur ada tidaknya kecurangan yang dilakukan oleh suatu perusahaan yaitu auditor pajak.

Berbeda dengan proporsi komisaris independen dan kualitas audit, hasil pengujian menunjukkan tidak ada pengaruh antara kepemilikan institusional terhadap penghindaran pajak. Penelitian ini sejalan dengan Annisa dan Kurniasih (2012), Maharani dan Suardana (2014), serta Jaya dan Arafat (2013) menemukan bahwa tidak ada pengaruh kepemilikan institusional terhadap penghindaran pajak. Perusahaan yang patuh terhadap pembayaran pajak tidak menimbang besarnya kepemilikan saham institusional, tetapi cenderung memperhatikan besarnya pajak yang dibayarkan dari pada melakukan praktik penghindaran pajak yang bisa merusak nama baik perusahaan. Artinya, citra perusahaan lebih penting dari pada melakukan penghindaran pajak dalam rangka meningkatkan laba perusahaan, sehingga penghindaran pajak tidak dipengaruhi oleh kepemilikan institusional.

Selanjutnya, hasil pengujian komite audit juga tidak berpengaruh terhadap penghindaran pajak. Hasil penelitian ini sejalan dengan Alviyani (2016) serta Swingly dan Sukartha (2015) menyatakan bahwa komite audit tidak memiliki pengaruh terhadap tax avoidance. Hal ini dikarenakan komite audit hanya berperan untuk melakukan pengawasan dan membantu dewan komisaris untuk menghasilkan laporan keuangan atau informasi yang berkualitas, tidak sampai membantu perusahaan untuk melakukan penghematan pajak malalui 
tax avoidance (Eksandy, 2017). Selain itu, Larastomo, Perdana, Triatmoko, dan Sudaryono (2016) mengungkapkan bahwa komite audit tidak berpengaruh terhadap penghindaran pajak disebabkan peran komite audit dalam tata kelola perusahaan hanya sebatas mengisi regulasi bukan untuk memenuhi good corporate governance. Oleh karena itu, komite audit tidak berpengaruh terhadap penghindaran pajak.

\section{Simpulan}

Berdasarkan hasil temuan dan analisis yang dilakukan, peneliti dapat menarik beberapa kesimpulan yaitu: pertama, proporsi komisaris independen dan kualitas audit memiliki pengaruh positif dan signifikan terhadap penghindaran pajak. Kedua, kepemilikan institusional dan komite audit tidak memiliki pengaruh terhadap penghindaran pajak. Dari hasil penelitian tersebut kiranya Direktorat Jenderal Pajak dapat memperhatikan tingkat proporsi komisaris independen dan kualitas audit pada setiap perusahaan agar dapat memaksimalkan penerimaan pajak.

Dalam penelitian ini, memiliki keterbatasan dalam mengakses laporan keuangam perusahaan, sehingga objek yang diteliti terbatas. Selain itu, indikator tax avoidance dalam penelitian ini hanya menggunakan BTD. Oleh karena itu, penelitian selanjutnya diharapkan dapat memperbanyak objek yang diteliti serta menggunakan indikator lain seperti Effective Tax Rate (ETR). Kemudian, penelitian selanjutnya diharapkan dapat mengunakan objek lain seperti perusahaan yang bergerak pada sektor properti, real estate dan konstruksi bangunan mengingat tingkat aktivitas ekonomi perusahaan cukup tinggi yang memungkinkan perusahaan melakukan penghindaran pajak atas laba yang diperoleh, dengan memperluas tahun, maupun menggunakan metode penelitian yang berbeda.

\section{Daftar Pustaka}

Alviyani, K. (2016). Pengaruh corporate governance, karakter eksekutif, ukuran perusahaan, dan leverage terhadap penghindaran pajak (studi pada perusahaan pertanian dan pertambangan yang terdaftar di BEI tahun 20112014). Jurnal Online Mahasiswa Fekon, 3(1), 2540-2554. Retrieved from https://media.neliti.com/media/publications/124720-ID-pengaruhcorporate-governance-karakter-e.pdf

Annisa, N. A., \& Kurniasih, L. (2012). Pengaruh corporate governance terhadap tax avoidance. Jurnal Akuntansi \& Auditing, 8(2), 95-189. Retrieved from https://media.neliti.com/media/publications/74390-ID-pengaruhcorporate-governance-terhadap-t.pdf 
Brian, I., \& Martani, D. (2014). Analisis pengaruh penghindaran pajak dan kepemilikan keluarga terhadap waktu pengumuman laporan keuangan tahunan perusahaan. Finance and Bankiing Journal, 16(2), 125-139. Retrieved from https://perbanas.id/jurnal/index.php/jkp/article/view/205/22

Bursa Efek Indonesia. (2018). Laporan Keuangan dan Tahunan. Retrieved from www.idx.co.id

Cai, H., \& Liu, Q. (2009). Competition and corporate tax avoidance: Evidence from chinese industrial firms. Economic Journal, 119(537), 764-795. Retrieved from https://econpapers.repec.org/article/ecjeconjl/v_3a119_3ay_3a2009_3ai_3a 537_3ap_3a764-795.htm

DeAngelo, L. E. (1981). Auditor independence, low balling, and disclosure regulation. Journal of Accounting and Economics, 3(2), 113-127. Retrieved from https://econpapers.repec.org/article/eeejaecon/v_3a3_3ay_3a1981_3ai_3a2_ 3ap_3a113-127.htm

Desai, M. A., \& Dharmapala, D. (2006). Corporate tax avoidance and high-powered incentives. Journal of Financial Economics, 79(1), 145-179. Retrieved from https://econpapers.repec.org/article/eeejfinec/v_3a79_3ay_3a2006_3ai_3a1_ 3ap_3a145-179.htm

Development, O. for E. C. and. (2004). Principles of corporate governance. Retrieved from

https://www.google.com/url?sa=t\&rct=j\&q=\&esrc=s\&source=web\&cd=1\&ve d=2ahUKEwjwv5Tt_ojfAhUFto8KHZ7HCyQQFjAAegQIBxAC\&url=http\%3A\%2 F\%2Fwww.oecd.org\%2Fcorporate\%2Fca\%2Fcorporategovernanceprinciples \%2F31557724.pdf\&usg=AOvVaw3c8qoPZquNmM4Z6c51S7r-

Dewi, G. A. P., \& Sari, M. M. R. (2015). Pengaruh insentif eksekutif, corporate risk dan corporate governance pada tax avoidance. E-Jurnal Akuntansi Universitas Udayana, 13(1), 50-67. Retrieved from https://ojs.unud.ac.id/index.php/Akuntansi/article/view/11423

Dewi, N. N. K., \& Jati, I. K. (2014). Pengaruh karakter eksekutif, karakteristik perusahaan, dan dimensi tata kelola perusahaan yang baik pada tax avoidance di Bursa Efek Indonesia. E-Jurnal Akuntansi Universitas Udayana, 6(2), 249$260 . \quad$ Retrieved from http://id.portalgaruda.org/?ref=browse\&mod=viewarticle\&article=143168

Eksandy, A. (2017). Pengaruh komisaris independen, komite audit, dan kualitas audit terhadap penghindaran pajak (studi empiris pada sektor industri barang konsumsi yang terdaftar di Bursa Efek Indonesia periode 2010-2014). Competitive, 1(1), 1-20. Retrieved from http://jurnal.umt.ac.id/index.php/competitive/article/download/96/57

Fadhilah, R. (2014). Pengaruh good corporate governance terhadap tax avoidance (studi empiris pada perusahaan manufaktur yang terdaftar di BEI 2009-2011). Jurnal Akuntansi, 2(1), 1-22. Retrieved from http://ejournal.unp.ac.id/students/index.php/akt/article/view/908/658

Granger, C. W. J., \& Newbold, P. (1974). Spurious regressions in econometrics. Journal of Econometrics, 2(2), 111-120. Retrieved from https://www.sciencedirect.com/science/article/pii/0304407674900347 
Gujarati, D. N., \& Poter, D. C. (2012). Dasar-dasar ekonometrika. Jakarta: Salemba Empat. Hanlon, M., \& Shane, H. (2010). A review of tax research. Journal of Accounting and Economics, 50(2-3), 127-178. Retrieved from https://econpapers.repec.org/article/eeejaecon/v_3a50_3ay_3a2010_3ai_3a 2-3_3ap_3a127-178.htm

Idzni, I. N., \& Purwanto, A. (2017). Pengaruh ketertarikan investor asing dan kepemilikan institusional terhadap penghindaran pajak perusahaan. Diponegoro Journal of Accounting, 6(1), 1-12. Retrieved from https://media.neliti.com/media/publications/244186-pengaruhketertarikan-investor-asing-dan-42684879.pdf

Jaya, T. E., \& Arafat, M. Y. (2013). Corporate governance, konservatisme akuntansi dan tax avoidance (Proceeding Simposium Nasional Perpajakan 4). Surabaya. Retrieved from https://www.scribd.com/document/366712025/ProsidingSimposium-Nasional-Perpajakan-4-Corporate-Governance-KonservatismeAkuntansi-Dan-Tax-Avoidance

Jensen, M. C., \& Meckling, W. H. (1976). The theory of the firm: Manajerial behaviour, agency cost, and ownership structure. Journal of Financial and Economics, 3(4), 305-360. Retrieved from https://papers.ssrn.com/sol3/papers.cfm?abstract_id=94043

Keuangan, D. J. P. K. (2013). Pembiayaan negara 70 persen dari pajak. Retrieved from http://www.pajak.go.id/content/pembiayaan-negara-70-persen-dari-pajak

Khurana, I. K., \& Moser, W. J. (2009). Institusional ownership and tax aggressiveness. Retrieved from https://poseidon01.ssrn.com/delivery.php?ID=89606508112302301609500 712011011602605807208500704802310510108707210611309011302610 210705302312200803706111707701400407110000104800802204404706 508701700908112100509304609411311201610906509011001009611711 40730691

Kompas.com. (2016). Beberapa profesi kurang taat pajak.

Lanis, R., \& Richardson, G. (2011). The effect of board of director composition on corporate tax aggressiveness. Journal of Accounting and Public Policy, 30(1), 50-70. $\quad$ Retrieved from https://econpapers.repec.org/article/eeejappol/v_3a30_3ay_3a_3ai_3a1_3ap _3a50-70.htm

Larastomo, J., Perdana, H. D., Triatmoko, H., \& Sudaryono, E. A. (2016). Pengaruh tata kelola perusahaan dan penghindaran pajak terhadap manajemen laba pada perusahaan manufaktur di Indonesia. Jurnal Bisnis Dan Manajemen, 6(1), 6374. https://doi.org/10.15408/ess.v6i1.3121

Maharani, I. G. A. C., \& Suardana, K. A. (2014). Pengaruh corporate governance, profitabilitas, dan karakteristik eksekutif tax avoidance perusahaan manufaktur. E-Jurnal Akuntansi Universitas Udayana, 9(2), 525-539. Retrieved from https://ojs.unud.ac.id/index.php/Akuntansi/article/view/9290

Mardiasmo. (2013). Perpajakan edisi revisi. Yogyakarta: Andi Offset.

Minnick, K., \& Noga, T. (2010). Do corporate governance characteristics influence tax management? Journal of Corporate Finance, 16(5), 703-718. Retrieved from 
https://econpapers.repec.org/article/eeecorfin/v_3a16_3ay_3a2010_3ai_3a5 _3ap_3a703-718.htm

Ngadiman, \& Puspitasari, C. (2014). Pengaruh leverage, kepemilikan institusional, dan ukuran perusahaan terhadap penghindaran pajak (tax avoidance) pada perusahaan sektor manufaktur yang terdaftar di Bursa Efek Indonesia 20102012. Jurnal Akuntansi, 18(3), 408-421. Retrieved from https://media.neliti.com/media/publications/74028-ID-none.pdf

Nindita, C. N., \& Siregar, S. V. (2012). Analisis pengaruh ukuran kantor akuntan publik terhadap kualitas audit di Indonesia. Jurnal Akuntansi Dan Keuangan, 14(2), 91-104. Retrieved from http://jurnalakuntansi.petra.ac.id/index.php/aku/article/view/18711

Patra, D. (2016). Kerugian korupsi tambang capai rp 4000 t. Retrieved from http://koran-sindo.com/page/news/2016-0831/0/16/Kerugian_Korupsi_Tambang_Capai_Rp4_000_T

Pemerintah Republik Indonesia. (2007). Undang-undang republik indonesia nomor 40 tahun 2007 tentang perseroan terbatas.

Pemerintah Republik Indonesia. (2009). Undang-undang nomor 16 tahun 2009 pasal 1 tentang ketentuan umum dan tata cara perpajakan.

Pemerintah Republik Indonesia. (2014). Peraturan otoritas jasa keuangan nomor 33/pojk.04/2014 Pasal 20 Ayat (3) tentang direksi dan dewan komisaris emiten atau perusahaan publik.

Pujiati, D., \& Widanar, E. (2009). Pengaruh struktur kepemilikan terhadadp nilai perusahaan: Keputusan keuangan sebagai variabel intervening. Jurnal Ekonomi Bisnis \& Akuntansi Ventura, 12(1), 71-86. Retrieved from https://www.researchgate.net/publication/279672196_Pengeruh_Corporate _Social_Responsibility_Terhadap_Nilai_Perusahaan_Dengan_Kepemilikan_Man ajemen_Sebagai_Variabel_Moderating

Robinson, J. R., Xue, Y., \& Zhang, M. H. (2012). Tax planning and financial expertise in the audit committee. Retrieved from https://poseidon01.ssrn.com/delivery.php?ID=20610007207211202708109 108408210307311604509307706504510211510910002511411000001111 800001700600603305111109706601701611109101810504006803609202 108609307102401402805004706310711911609207007012409011611210 81140741

Sabli, N., \& Noor, R. M. (2012). Tax planning and corporate governance (Proceeding 3 rd International Conference on Business and Economic Research (3rd ICBER 2012)).

Siregar, R., \& Widyawati, D. (2016). Pengaruh karakteristik perusahaan terhadap penghindaran pajak pada perusahaan manufaktur di BEI. Jurnal Ilmu Dan Riset Akuntansi, 5(2), 1-17. Retrieved from http://garuda.ristekdikti.go.id/journal/article/524279

Sriwedari, T. (2012). Mekanisme good corporate governance, manajemen laba dan kinerja keuangan perusahaan manufaktur di Bursa Efek Indonesia. Jurnal Mediasi, 4(1), 78-88. Retrieved from http://digilib.unimed.ac.id/416/1/Fulltext.pdf 
Suandy, E. (2011). Perencanaan pajak edisi 5. Jakarta: Salemba Empat.

Suryana, A. (2005). Pengaruh komite audit terhadap kualitas laba. Surakarta. Retrieved from https://smartaccounting.files.wordpress.com/2011/03/kakpm-07.pdf

Swingly, C., \& Sukartha, I. M. (2015). Pengaruh karakteristik eksekutif, komite audit, ukuran perusahaan, leverage dan sales growth pada tax avoidance. E-Jurnal Akuntansi Universitas Udayana, 10(1), 47-62. Retrieved from https://ojs.unud.ac.id/index.php/Akuntansi/article/view/9863/0

Tang, T. Y. H., \& Firth, M. (2012). Earnings persistence and stock market reactions to the different information in book-tax differences: Evidence from China. The International Journal of Accounting, 47(3), 369-397. Retrieved from https://www.sciencedirect.com/science/article/pii/S0020706312000647

Timothy, Y. C. K. (2010). Effect of corporate governance on tax aggressinveness. Hong Kong Baptist University. Retrieved from http://libproject.hkbu.edu.hk/trsimage/hp/07014341.pdf

Tribunnews.com. (2017). Indonesia masuk peringkat ke-11 penghindaran pajak perusahaan, Jepang no. 3 Artikel ini telah tayang di Tribunnews.com dengan judul Indonesia Masuk Peringkat ke-11 Penghindaran Pajak Perusahaan, Jepang No.3, http://www.tribunnews.com/internasional/2017/11. Retrieved from http://www.tribunnews.com/internasional/2017/11/20/indonesiamasuk-peringkat-ke-11-penghindaran-pajak-perusahaan-jepang-no3

Winarno, W. W. (2015). Analisis ekonometrika dan statistika dengan eviews. Yogyakarta: UPP STIM YKPN.

Winata, F. (2014). Pengaruh corporate governance terhadap tax avoidance pada perusahaan yang terdaftar di Bursa Efek Indonesia tahun 2013. Tax and Accounting Review, 4(1), 1-11. Retrieved from https://media.neliti.com/media/publications/157323-ID-none.pdf 